\title{
Morphometrical Studies on the Skull of Indian Blackbuck (Antelope cervicapra)
}

\author{
Estudios Morfológicos en el Cráneo del Antílope Indio (Antelope cervicapra)
}

\author{
Om Prakash Choudhary* \& Ishwer Singh**
}

CHOUDHARY, O. P. \& SINGH, I. Morphometrical studies on the skull of Indian Blackbuck (Antelope cervicapra). Int. J. Morphol., 33(3):868-876, 2015.

SUMMARY: The phenotypic appearance of the head of animal species depends strongly on the shape of the skull. The morphometric studies of the skull show that variability in the shape and proportions of bones is influenced by genetic and environmental factors. The present study was carried out first time on the morphometrical characteristics on skull of Indian Blackbuck. Craniometric measurements for 48 different parts of the skulls of Indian blackbuck were made in this study. All investigated features were expressed as Mean \pm SE. The craniometric measurements and cephalic indices had been compared with ruminants. The mean lengths of the skulls were found to be $20.68 \pm 0.02 \mathrm{~cm}$, with the width and cephalic index to the magnitude of $9.54 \pm 0.03 \mathrm{~cm}$ and $46.12 \pm 0.12 \mathrm{~cm}$, respectively. The cranial length, width and height in blackbuck were $10.40 \pm 0.02 \mathrm{~cm}, 6.13 \pm 0.02 \mathrm{~cm}$ and $7.13 \pm 0.02 \mathrm{~cm}$, respectively. The cranial index was $59.00 \pm 0.11$. The mean facial length, facial width and facial index were $11.53 \pm 0.08 \mathrm{~cm}, 9.30 \pm 0.01 \mathrm{~cm}$ and $80.67 \pm 0.44 \mathrm{~cm}$, respectively. The mean weight of the skull with mandible in blackbuck was $182.37 \pm 0.54$.

KEY WORDS: Blackbuck; Skull; Morphometrical; Cephalic index; Cranial index.

\section{INTRODUCTION}

The blackbuck (Antilope cervicapra) is an ungulate species of antelope native to the Indian Subcontinent that has been classified as near threatened by IUCN since 2003, as its range has decreased sharply during the 20th century. The blackbuck is protected under Schedule I of the Indian Wildlife Protection Act., 1972.

The phenotypic appearance of the head of animal species depends strongly on the shape of the skull (Künzel et al., 2014). These studies have been undertaken in many domestic species such as the dog (Onar \& Günes, 2003; McGreevy et al., 2004), cats (Künzel et al.), goats (Olopade \& Onwuka, 2004, 2009a, 2009b), horses (Evans \& McGreevy, 2006) and sheep (Pare's et al., 2010) in an attempt to provide baseline anatomic information and evaluate implications for physiological functions and clinical importance (Olopade \& Onwuka, 2009a). The skull has also been used as a major skeletal structure to determine taxonomic affiliations as it is subject to phenotypic changes because of selective breeding (Bruenner et al., 2002). The occipital bone is frequently studied in procedures of gender determination in forensics or anthropology (Rogers, 2005).
The aim of this study is to investigate osteometrical parameters of the skull of Indian blackbuck, thereby making a contribution in filling the gap of knowledge in this field. The knowledge of morphometric measurements of skull is of great importance for surgical treatment of pathological conditions and taxonomic affiliation.

\section{MATERIAL AND METHOD}

The present study was conducted on six skull of adult Indian Blackbuck (Antelope cervicapra) of either sex. The permission for the specimen collection was sought from the Deputy Inspector General (WL), Ministry of Environment and Forests (MoEF), New Delhi, India and Principal Chief Conservator of Forest (PCCF), Government of Rajasthan. The skeletons were collected from the Jodhpur zoo after official approvals from the Principal Chief Conservator of Forest (PCCF) vide letter no. F, 3 (02) Tech-II/CCF/2010/ 714 dated 07.05.2014. The skeletons were dug out from the graveyards located in the premises of Jodhpur zoo. The skulls

* Ph.D. Scholar; Department of Veterinary Anatomy, G.B. Pant University of Agriculture and Technology, Pantnagar, India.

** Professor and Head Department of Veterinary Anatomy, College of Veterinary and Animal Science, G.B. Pant University of Agriculture and Technology, Pantnagar, India. 
were macerated using the hot water maceration technique of Olopade \& Onwuka (2004) and modified by the authors by adding potassium hydroxide to the boiling process, which was performed at $100{ }^{\circ} \mathrm{C}$ for at least $50 \mathrm{~min}$ and followed by further boiling in water for another 30-40 min after careful separating the mandibles from the skulls.

The osteometrical studies were carried out in Jodhpur zoo under supervision of the zoo personnel. Different parameters of the skull were measured and subjected to routine statistical analysis (Snedecor \& Cochran, 1994). This study was designed to provide maximum number of biometrical parameters of skull and some information on clinically important parameters of blackbuck. The following measurements were taken for different bones of the skull and were summarized in Table I.

1. Skull parameters (Figs. 1 and 2)

a) Length (Lsk): Distance between the highest points of the parietals to the middle of the rostral margin of the incisive bone.

b) Width (Wsk): Distance between two zygomatic arches. c) Skull/cephalic index (SI): Skull width/ Skull length X 100 Miller et al. (1964).

d) Skull base length (LBsk): Distance between the midpoints of the dorsal margin of the foramen magnum to the level of the middle point of the rostral margin of the incisive bone.

2. Cranial parameters (Fig. 1):

a) Cranial length (Hcr): Distance from the central point of the fronto-nasal suture to the middle point of the nuchal crest.

b) Cranial width (Wcr): Maximum distance between the bases of the horns.

c) Cranial index (CrI): Cranial width/ Cranial length $\mathrm{X}$ 100 Miller et al.

d) Cranial height (Hcr): Distance between the central points of the dorsal rim of the foramen magnum to the point of the origin of interfrontal suture.

e) Capacity of the cranial cavity: All the foramina of the cranial cavity were plugged with cotton. The cavity was then filled with mustard grains through the foramen magnum up to its brim. The mustard was then emptied into a measuring cylinder to get the capacity.

3. Orbital parameters (Fig. 3):

a) Orbital length (Lo): The perpendicular distance between the supraorbital and infraorbital margins of the orbit.

b) Orbital width (Wo): The horizontal distance between the rostral and caudal margins of the orbital rim.

c) Orbital index (OI): Orbital width/ Orbital length X 100 Miller et al.

d) Orbital depth (Do): Distance between optic foramen and center of the orbital rim.

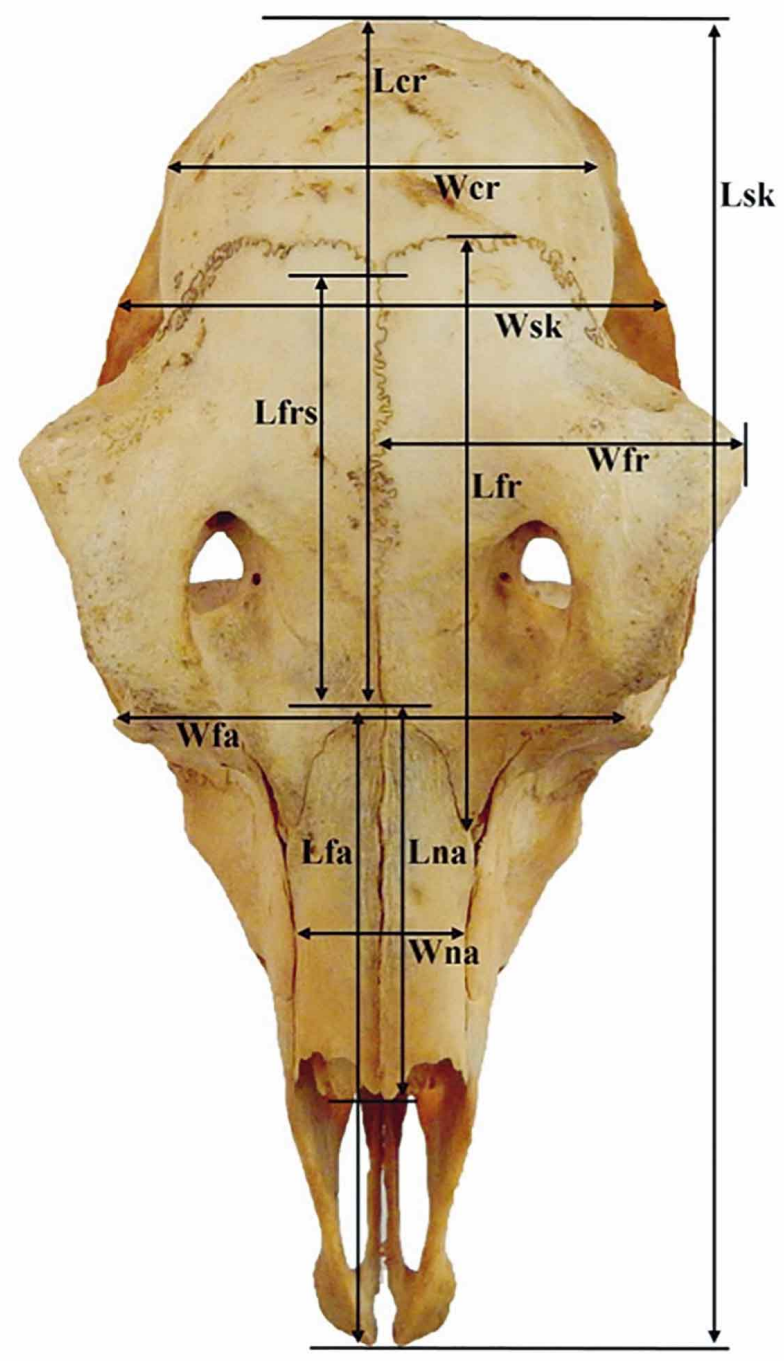

Fig. 1. Measurements of the skull (dorsal view) showing cranial length (Lcr), cranial width (Wcr), facial length (Lfa), facial width (Wfa), length of skull (Lsk), width of skull (Wsk), length of frontal (Lfr), width of frontal (Wfr), length of frontal suture (Lfrs), length of nasal (Lna) and width of nasal bone (Wna).

e) Orbital capacity: All the foramina of the orbital cavity were plugged with cotton. The cavity was then filled with mustard grains up to its brim. The mustard was then emptied into a measuring cylinder to get the capacity.

f) Orbital circumference length (Oc): Maximum circumference of the orbit, along the rim.

g) Orbital area: $22 / 7 * \mathrm{AB}$, where $\mathrm{A}$ and $\mathrm{B}$ are the halves of orbital length and width, respectively.

4. Facial parameters (Fig. 1):

a) Facial length (Lfa): Distance from the fronto-nasal suture to the center of the incisive bone.

b) Facial width (Wfa): Distance between the caudal extents of the orbital rims. 
Table I. Morphometric data of the skull of the Indian Blackbuck (Antelope cervicapra).

\begin{tabular}{|c|c|c|c|c|c|}
\hline Sr. & Parameters of bones of the Skull of Indian Blackbuck & Range (cm) & Mean (cm) & Female Mean \pm SE & Male Mean \pm SE \\
\hline 1. & Maximum length (Lsk) & $20.62-20.75$ & $20.68 \pm 0.02$ & $20.63 \pm 0.007$ & $20.73 \pm 0.01$ \\
\hline 2. & Maximum width (Wsk) & $9.46-9.63$ & $9.54 \pm 0.03$ & $9.46 \pm 0.008$ & $9.61 \pm 0.01$ \\
\hline 3. & Skull/Cephalic Index (SkI) & $45.83-46.43$ & $46.12 \pm 0.12$ & $45.88 \pm 0.04$ & $46.37 \pm 0.04$ \\
\hline 4. & Skull base length (LBsk) & $18.24-18.38$ & $18.31 \pm 0.02$ & $18.26 \pm 0.01$ & $18.36 \pm 0.01$ \\
\hline 5. & Cranial length (Lcr) & $10.36-10.47$ & $10.40 \pm 0.02$ & $10.36 \pm 0.004$ & $10.41 \pm 0.02$ \\
\hline 6. & Cranial wid th (Wcr) & $6.08-6.21$ & $6.13 \pm 0.02$ & $6.09 \pm 0.004$ & $6.18 \pm 0.02$ \\
\hline 7. & Cranial Index (CrI) & $58.68-59.31$ & $59.00 \pm 0.11$ & $58.79 \pm 0.08$ & $59.22 \pm 0.09$ \\
\hline 8. & Cranial height (Hcr) & $7.06-7.18$ & $7.13 \pm 0.02$ & $7.08 \pm 0.01$ & $7.17 \pm 0.008$ \\
\hline 9. & Capacity of Cranial cavity $\left(\mathrm{Cm}^{3 /} \mathrm{ml}\right)$ & $106-111$ & $107.83 \pm 0.86$ & $106.33 \pm 0.04$ & $109.33 \pm 1.08$ \\
\hline 10. & Facial length (Lfa) & $11.33-11.71$ & $11.53 \pm 0.08$ & $11.37 \pm 0.03$ & $11.70 \pm 0.007$ \\
\hline 11. & Facial width (Wfa) & $9.27-9.34$ & $9.30 \pm 0.015$ & $9.27 \pm 0.008$ & $9.33 \pm 0.004$ \\
\hline 12. & Facial Index (FI) & $79.67-81.81$ & $80.67 \pm 0.44$ & $81.56 \pm 0.24$ & $79.79 \pm 0.079$ \\
\hline 13. & Orbit height (Lo) & $3.80-3.88$ & $3.83 \pm 0.02$ & $3.83 \pm 0.01$ & $3.84 \pm 0.01$ \\
\hline 14. & Orbit length (Wo) & $4.03-4.25$ & $4.13 \pm 0.02$ & $4.12 \pm 0.04$ & $4.14 \pm 0.04$ \\
\hline 15. & Orbital Index (ObI) & $106-110$ & $107.33 \pm 0.41$ & $107.00 \pm 0.48$ & $107.66 \pm 1.00$ \\
\hline 16. & Orbital depth(Do) & $4.59-4.67$ & $4.61 \pm 0.008$ & $4.61 \pm 0.01$ & $4.62 \pm 0.01$ \\
\hline 17. & Orbital capacity $\left(\mathrm{Cm}^{3}\right)$ & 23-29 & $26.25 \pm 0.50$ & $25.00 \pm 0.56$ & $27.50 \pm 0.37$ \\
\hline 18. & Orbital circumference $(\mathrm{Oc})$ & $13.06-13.53$ & $13.29 \pm 0.06$ & $13.30 \pm 0.10$ & $13.29 \pm 0.09$ \\
\hline 19. & Orbital area $\left(\mathrm{Cm}^{2}\right)$ & $12.00-12.88$ & $12.46 \pm 0.10$ & $12.43 \pm 0.17$ & $12.50 \pm 0.16$ \\
\hline 20. & Length of maxilla (Lma) & $9.28-9.31$ & $9.29 \pm 0.005$ & $9.28 \pm 0.04$ & $9.30 \pm 0.04$ \\
\hline 21. & Width of maxil la (Wma) & $4.81-4.86$ & $4.83 \pm 0.008$ & $4.81 \pm 0.004$ & $4.85 \pm 0.007$ \\
\hline 22. & $(\mathrm{ft}-\mathrm{io})$ & $2.35-2.39$ & $2.37 \pm 0.006$ & $2.35 \pm 0.04$ & $2.38 \pm 0.04$ \\
\hline 23. & (io-rat) & $0.69-0.75$ & $0.72 \pm 0.01$ & $0.70 \pm 0.007$ & $0.74 \pm 0.007$ \\
\hline 24. & Length of premaxilla (Lpm) & $7.22-7.26$ & $7.23 \pm 0.007$ & $7.22 \pm 0.004$ & $7.25 \pm 0.007$ \\
\hline 25. & Width of premaxilla (Wpm) & $0.97-1.03$ & $1.00 \pm 0.001$ & $0.98 \pm 0.007$ & $1.02 \pm 0.007$ \\
\hline 26. & Length of lacrimal (Lla) & $4.32-4.41$ & $4.36 \pm 0.01$ & $4.32 \pm 0.008$ & $4.40 \pm 0.007$ \\
\hline 27. & Width of lacrimal (Wla) & $1.68-1.75$ & $1.71 \pm 0.01$ & $1.69 \pm 0.007$ & $1.73 \pm 0.01$ \\
\hline 28. & length of nasal (Lna) & $5.66-5.73$ & $5.69 \pm 0.01$ & $5.66 \pm 0.008$ & $5.72 \pm 0.007$ \\
\hline 29. & width of nasal (Wna) & $1.26-1.33$ & $1.29 \pm 0.01$ & $1.27 \pm 0.007$ & $1.31 \pm 0.01$ \\
\hline 30. & length of palatine (Lpa) & $5.93-6.14$ & $6.04 \pm 0.046$ & $5.94 \pm 0.01$ & $6.13 \pm 0.008$ \\
\hline 31. & Width of palatine (Wpa) & $3.17-3.29$ & $3.23 \pm 0.022$ & $3.18 \pm 0.01$ & $3.27 \pm 0.01$ \\
\hline 32. & Height of occipital (Hoc) & $5.16-5.24$ & $5.21 \pm 0.01$ & $5.17 \pm 0.008$ & $5.22 \pm 0.01$ \\
\hline 33. & Width of occipital (Woc) & $5.74-5.79$ & $5.76 \pm 0.008$ & $5.75 \pm 0.01$ & $5.78 \pm 0.004$ \\
\hline 34. & Inter-condylar width (Wic) & $4.58-4.68$ & $4.62 \pm 0.01$ & $4.59 \pm 0.01$ & $4.66 \pm 0.01$ \\
\hline 35. & Inter-paracondylar width (Wipc) & $5.27-5.33$ & $5.29 \pm 0.01$ & $5.27 \pm 0.008$ & $5.31 \pm 0.01$ \\
\hline 36. & Height of foramen magnum (Hfm) & $1.71-1.76$ & $1.74 \pm 0.008$ & $1.72 \pm 0.01$ & $1.75 \pm 0.04$ \\
\hline 37. & Width of foramen magnum (Wfm) & $2.02-2.06$ & $2.03 \pm 0.006$ & $2.02 \pm 0.004$ & $2.05 \pm 0.007$ \\
\hline 38. & Area of foramen magnum $\left(\mathrm{Cm}^{2}\right)$ & $0.86-0.90$ & $0.88 \pm 0.006$ & $0.86 \pm 0.004$ & $0.89 \pm 0.004$ \\
\hline 39. & Circumference of foramen magnum & $8.17-8.28$ & $8.22 \pm 0.01$ & $8.19 \pm 0.01$ & $8.26 \pm 0.01$ \\
\hline 40. & Height of palatine (Hpa) & $4.15-4.19$ & $6.04 \pm 0.046$ & $4.16 \pm 0.007$ & $4.18 \pm 0.007$ \\
\hline 41. & Width of palatine(W pa) & $6.12-6.19$ & $6.16 \pm 0.01$ & $6.14 \pm 0.01$ & $6.18 \pm 0.004$ \\
\hline 42. & Length of frontal (Lfr) & $7.72-7.79$ & $7.75 \pm 0.01$ & $7.73 \pm 0.01$ & $7.77 \pm 0.01$ \\
\hline 43. & Width of frontal (Wfr) & $4.79-4.84$ & $4.81 \pm 0.008$ & $4.80 \pm 0.01$ & $4.83 \pm 0.007$ \\
\hline 44. & length of frontal suture (Lfrs) & $5.44-5.49$ & $5.46 \pm 0.008$ & $5.45 \pm 0.007$ & $55.48 \pm 0.007$ \\
\hline 45. & Distance from lateral alveolar root to mental foramen & $2.41-2.51$ & $2.45 \pm 0.008$ & $2.43 \pm 0.00$ & $2.48 \pm 0.00$ \\
\hline 46. & Dist ance from Mental foramen to the caudal mandibular margin & $13.38-13.48$ & $13.43 \pm 0.081$ & $13.40 \pm 0.00$ & $13.45 \pm 0.00$ \\
\hline 47. & Mandibular length & $16.50-16.58$ & $16.53 \pm 0.12$ & $16.51 \pm 0.00$ & $16.56 \pm 0.00$ \\
\hline 48. & Mandibular height & $10.64-10.76$ & $10.69 \pm 0.024$ & $10.66 \pm 0.00$ & $10.73 \pm 0.00$ \\
\hline
\end{tabular}

c) Facial index (FI): Facial width/Facial length X 100 Miller et al.

5. Maxilla parameters (Fig. 3):

a) Length of maxilla (Lma): Maximum distance from parietal-frontal suture to the fronto-nasal suture.

b) Width of maxilla (Wma): Maximum distance from interfrontal suture to the rim of the orbit.

6. Premaxilla parameters (Fig. 3): 
a) Length of premaxilla (Lpm): Maximum length of premaxilla.

b) Width of premaxilla (Wpm): Maximum width of premaxilla.

7. Lacrimal parameters (Fig. 3):

a) Length of lacrimal (Lla): Distance from the fronto-lacrimal suture to the junction between the lacrimal and maxilla bone.

b) Width of lacrimal (Wla): Distance from the fronto-lacrimal suture to the junction between the lacrimal and malar bone.

8. Nasal parameters (Fig. 1):

a) Length of nasal bone (Lna): Distance from the central point of the fronto-nasal suture to the rostral end of the internasal suture.

b) Width across nasal bone (Wna): Maximum distance across the nasal bones or maximum distance between the naso-maxillary sutures.

9. Palatine parameters (Fig. 2):

a) Length of palate (Lpa): Distance measured from the rostral mid sutured line of incisive bone to the caudal nasal spine of the palatine bone.

b) Width of palate (Wpa): Maximum distance at the horizontal plate of palatine bone behind the last molar tooth.

10. Occipital parameters (Fig. 4):

a) Length of occipital (Loc): Maximum distance between external borders of two paracondylar processes.

b) Height of occipital (Hoc): Distance from base of the occipital condyle to the starting point of sagittal crest.

c) Intercondylar width (Wic): Width between the lateral ends of the occipital condyles.

d) Interparacondylar width (Wipc): Width between the lateral ends of the paracondylar process.

e) Height of foramen magnum ( $\mathrm{Hfm})$ : The distance between the midpoints of the dorsal ventral rims of the foramen magnum.

f) Width of foramen magnum (Wfm): The maximum distance between the two occipital condyles.

g) Foramen magnum index (FMI): Foramen magnum height/Foramen magnum width $X 100$

h) Area of foramen magnum: Calculated by using the formula- $\approx$ $* \mathrm{WH}$, where $\mathrm{W}=$ width and $\mathrm{H}=$ height of the foramen magnum.

i) Circumference of foramen magnum: Length of the entire rim of the foramen magnum.

11. Parietal parameters (Fig. 4):

a) Height of parietal (Hpa): Maximum height of parietal.

b) Width of parietal (Wpa): Maximum width of parietal.

12. Frontal parameters (Fig. 1):

a) Length of frontal (Lfr): Maximum length between parito-frontal suture and fronto-nasal suture.

b) Height of frontal (Hfr): Distance from naso-maxillary suture to the lateral extent of the alveolar root of lower incisor.

c) Length of frontal suture (Lfrs): Maximum length between parito-frontal suture and fronto-nasal suture.

13. Mandible:

a) Lateral alveolar root to mental foramen: Shortest distance from the mental foramen to the lateral extent of the alveolar root of lower incisor.

b) Mental foramen to the caudal mandibular border: From the

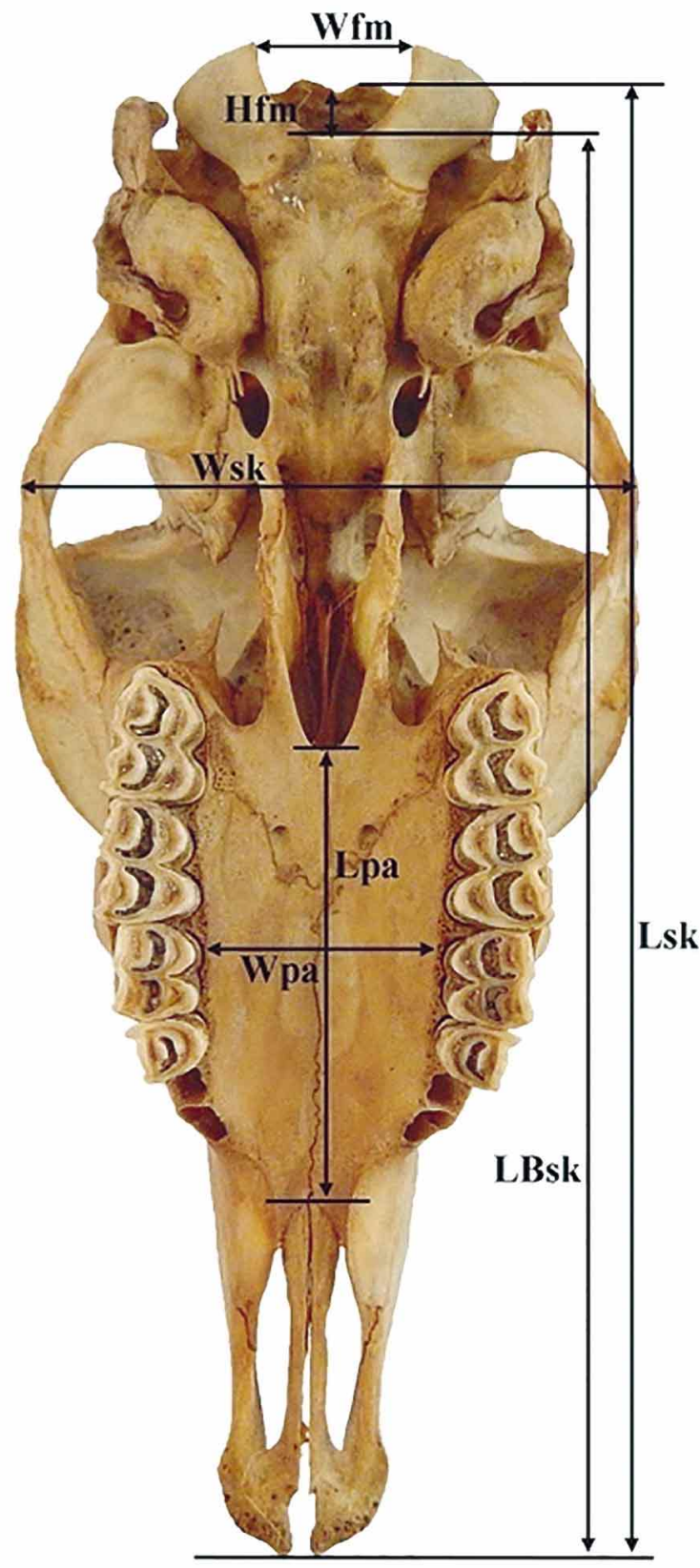

Fig. 2. Measurements of the skull (ventral view) showing width of foramen magnum (Wfm), height of foramen magnum (Hfm), length of skull (Lsk), width of skull (Wsk), length of palatine (Lpa) and width of palatine (Wpa).

level of the mental foramen to the extreme caudal border of the mandible.

c) Mandibular length: From the level of the cranial extremity of the alveolar root of the incisor to the level of the caudal border of the mandible.

d) Maximum mandibular height: From the basal level of the mandible to the highest level of the coronoid process. 

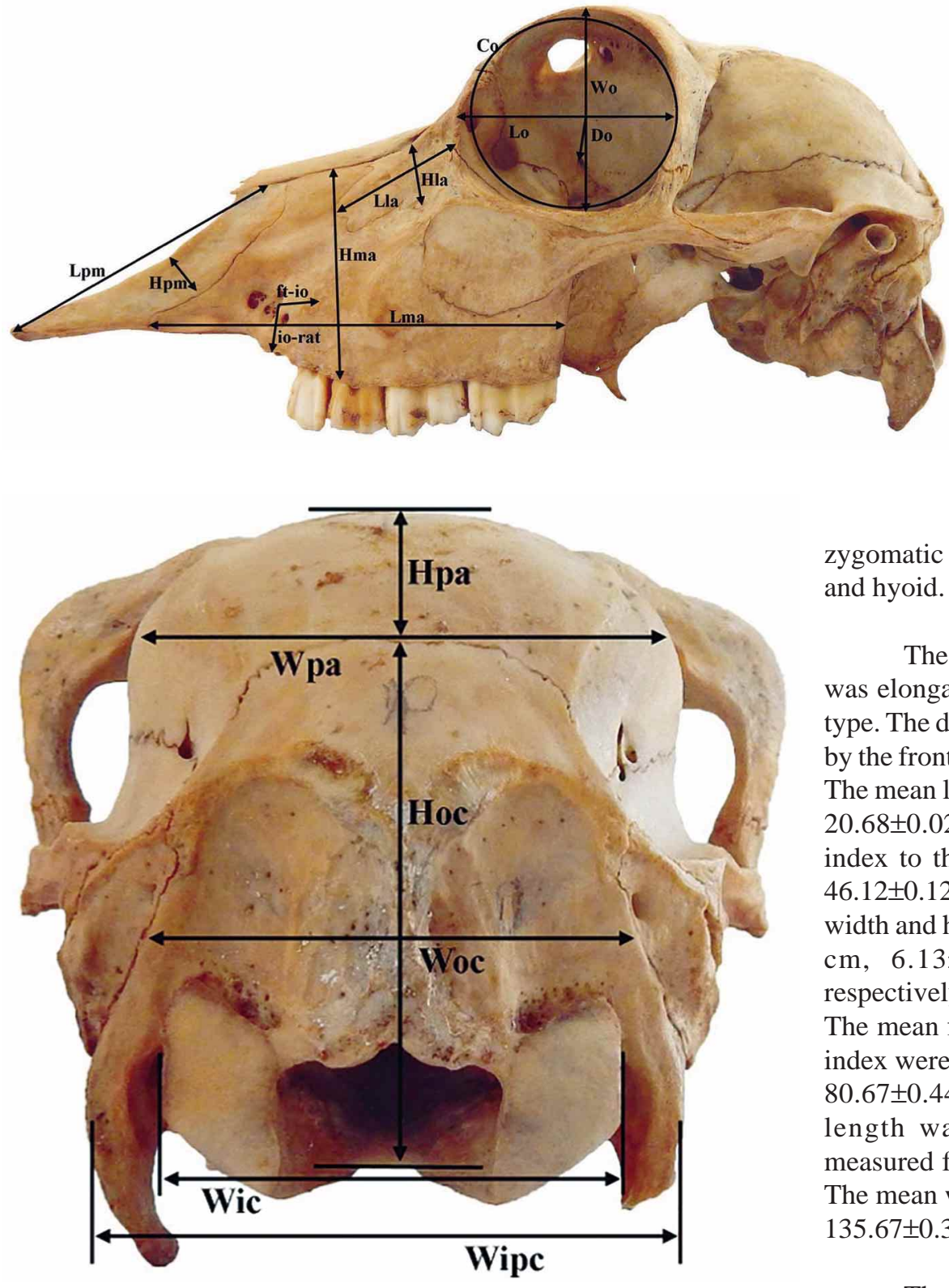

Fig. 4. Measurements of the skull (nuchal view) showing height of parietal (Hpa), width of parietal (Wpa), height of occipital (Hoc), width of occipital (Woc), intercondylar width (Wic) and interparacondylar width (Wipc).

\section{RESULTS}

The skull comprised of two essential parts- the cranial (Ossacranii) and the facial (Ossa-faciei). The number of skull bones was thirty two of which there were eleven cranial (three single and four paired) and twenty one facial (one single and the rest were paired) bones. The bones of the cranium were occipital, sphenoid, ethmoid, interparietal, parietal, frontal and temporal. The facial bones were maxilla, incisive (premaxilla), palatine, pterygoid, nasal, lacrimal,
Fig. 3. Measurements of the skull (lateral view) showing length of premaxilla $(\mathrm{Lpm})$, height of premaxilla $(\mathrm{Hpm})$, length of maxilla (Lm), height of maxilla $(\mathrm{Hm})$, length of lacrimal (Lla), height of lacrimal (Hla), distance from the facial tuberosity to the infra-orbital canal (ft-io), distance from infra-orbital canal to root of the alveolar tooth (ftrat), length of orbit (Lo), width of orbit (Wo), depth of orbit (Do) and circumference of orbit (Co). zygomatic (malar), turbinates, vomer, mandible and hyoid.

The measurements showed that the skull was elongated in shape and dolichocephalic in type. The dorsal surface (Fig. 1) was constituted by the frontal, parietal, nasal and incisive bones. The mean lengths of the skulls were found to be $20.68 \pm 0.02 \mathrm{~cm}$, with the width and cephalic index to the magnitude of $9.54 \pm 0.03 \mathrm{~cm}$ and $46.12 \pm 0.12 \mathrm{~cm}$, respectively. The cranial length, width and height in blackbuck were $10.40 \pm 0.02$ $\mathrm{cm}, 6.13 \pm 0.02 \mathrm{~cm}$ and $7.13 \pm 0.02 \mathrm{~cm}$, respectively. The cranial index was $59.00 \pm 0.11$. The mean facial length, facial width and facial index were $11.53 \pm 0.08 \mathrm{~cm}, 9.30 \pm 0.015 \mathrm{~cm}$ and $80.67 \pm 0.44 \mathrm{~cm}$, respectively. The skull base length was $18.31 \pm 0.02 \mathrm{~cm}$ in blackbuck measured from the ventral surface of the skull. The mean weight of the skull in blackbuck was $135.67 \pm 0.34$.

The orbits (Fig. 3) were complete, oval and placed rostro-laterally formed by the frontal, lacrimal and zygomatic bones; the highest contribution in the formation of the bony orbit was by the frontals followed by the zygomatic and the lacrimal. The orbital rim was almost circular in shape in blackbuck. Various orbital parameters showed bilateral variation among the orbits of both the sides. The orbital length and height $(4.22 \pm 0.009 \mathrm{~cm}$ and $3.86 \pm 0.005 \mathrm{~cm}$, respectively) was more in left than right orbit $(4.04 \pm 0.007 \mathrm{~cm}$ and $3.81 \pm 0.004 \mathrm{~cm}$, respectively). The average maximum height, length and depth of the orbit were $3.83 \pm 0.02 \mathrm{~cm}$, $4.13 \pm 0.02 \mathrm{~cm}$ and $4.61 \pm 0.008 \mathrm{~cm}$, respectively. 
The orbital area, circumference and the orbital index were $12.46 \pm 0.10,13.29 \pm 0.06$ and $107.33 \pm 0.41 \mathrm{~cm}$, respectively. The orbital capacity was $26.25 \pm 0.50 \mathrm{~cm}^{3}$ in blackbuck.

The cranial cavity was an ovoid cavity being elongated posteriorly, situated on the dorsal aspect of the nasal sinus. The capacity of cranial cavity was $107.83 \pm 0.86$ cm3 in blackbuck.

The maximum height and width of the occipital bone was $5.21 \pm 0.01 \mathrm{~cm}$ and $5.76 \pm 0.008 \mathrm{~cm}$, respectively. The maximum intercondylar and interparacondylar width was $4.62 \pm 0.01 \mathrm{~cm}$ and $5.29 \pm 0.01 \mathrm{~cm}$, respectively. The foramen magnum (foramen occipital magnum) was large and roughly oval. The height, width, circumference and area of the foramen magnum in blackbuck were $1.74 \pm 0.008 \mathrm{~cm}$, $2.03 \pm 0.006 \mathrm{~cm}, 8.22 \pm 0.01 \mathrm{~cm}$ and $0.88 \pm 0.006 \mathrm{~cm}^{2}$, respectively. The foramen index was 98.71 in Indian Blackbuck. The maximum height and width of the parietal bone was $4.17 \pm 0.006 \mathrm{~cm}$ and $6.16 \pm 0.01 \mathrm{~cm}$, respectively. The maximum length and width of the frontal bone was $7.75 \pm 0.01 \mathrm{~cm}$ and $4.81 \pm 0.008 \mathrm{~cm}$, respectively. The maximum length of the interfrontal suture was $5.46 \pm 0.008$ $\mathrm{cm}$.

The height of a supraorbital foramen in frontals was larger in right side $(1.02 \pm 0.00 \mathrm{~cm})$ than the left one $(0.84 \pm 0.00 \mathrm{~cm})$; while the average maximum height of a supraorbital foramen in blackbuck was $0.93 \pm 0.0237 \mathrm{~cm}$. The maximum length and width of the maxilla bone was $9.29 \pm 0.005 \mathrm{~cm}$ and $4.83 \pm 0.008 \mathrm{~cm}$, respectively.

The distance from the facial tuberosity to the infraorbital canal (ft-io) and from the latter to the root of the alveolar tooth directly ventral to it (io-rat), were $2.37 \pm 0.006$ $\mathrm{cm}$ and $0.72 \pm 0.01 \mathrm{~cm}$, respectively in blackbuck.

The maximum length and width of the premaxilla was $7.23 \pm 0.007 \mathrm{~cm}$ and $1.00 \pm 0.001 \mathrm{~cm}$, respectively. The maximum length and width of palatine bone was $6.04 \pm 0.046 \mathrm{~cm}$ and $3.23 \pm 0.022 \mathrm{~cm}$, respectively.

The average maximum length and width of nasal bone was $5.69 \pm 0.01 \mathrm{~cm}$ and $1.29 \pm 0.01 \mathrm{~cm}$, respectively. The length and width of the lacrimal bone was $4.36 \pm 0.01$ $\mathrm{cm}$ and $1.71 \pm 0.01 \mathrm{~cm}$, respectively. The distance between the lateral ends of the alveolus of the third incisor tooth to the mental foramen was $2.45 \pm 0.008$; which was an important landmark for achieving the location of the mental nerve for the regional nerve block in blackbuck. The length, height and weight of the mandible were $16.53 \pm 0.128$ $\mathrm{cm}, 10.69 \pm 0.024 \mathrm{~cm}$ and $46.67 \pm 0.17$ respectively in blackbuck.

\section{DISCUSSION}

The skull comprised of two essential parts- the cranial (Ossa cranii) and the facial (Ossa faciei). The number of skull bones was thirty two of which there were eleven cranial (three single and four paired) and twenty one facial (one single and the rest were paired) bones. The bones of the cranium were occipital, sphenoid, ethmoid, interparietal, parietal, frontal and temporal. The facial bones were maxilla, incisive (premaxilla), palatine, pterygoid, nasal, lacrimal, zygomatic (malar), turbinates, vomer, mandible and hyoid similar to the observations of Raghavan (1964) in ox, Miller et al. in dog, Sisson (1964) in ruminants, Getty (1975) in horse, Singh (1984) in camel and Kumawat et al. (2014) in chital.

The measurements demonstrated that the skull was elongated in shape as also reported in Kagani goat (Sarma, 2006) and in chital (Kumawat et al.). The skull of blackbuck was dolichocephalic in type similar to findings in chital (Kumawat et al.); whereas in tiger, it was brachycephalic (Joshi, 2004) and in dog, it was mesaticephalic (Miller et al.).

This dorsal surface was constituted by the frontal, parietal, nasal and incisive bones similar to the findings of Sarma in Kagani goats and Kumawat et al. in chital. The mean lengths of the skulls were found to be $20.68 \pm 0.02 \mathrm{~cm}$, with the width and cephalic index to the magnitude of $9.54 \pm 0.03 \mathrm{~cm}$ and $46.12 \pm 0.12 \mathrm{~cm}$, respectively; while according to Sarma in Kagani goats; the mean lengths of the skulls were $24.72 \pm 0.93 \mathrm{~cm}$, with the width and cephalic index of $10.40 \pm 0.61 \mathrm{~cm}$ and $41.95 \pm 0.97 \mathrm{~cm}$, respectively; whereas the skull length was $20.06 \pm 1.71 \mathrm{~cm}$ in Mehraban sheep (Karimi et al., 2011). Zhu et al. (2014) noted skull length and width $443.07 \pm 53.57 \mathrm{~mm}$ and $169.09 \pm 17.64 \mathrm{~mm}$ in donkey.

The cranial length, width and height in blackbuck were $10.40 \pm 0.02 \mathrm{~cm}, 6.13 \pm 0.02 \mathrm{~cm}$ and $7.13 \pm 0.02 \mathrm{~cm}$, respectively. The cranial index was $59.00 \pm 0.11$; whereas the cranial length and cranial index was $11.98 \pm 0.24 \mathrm{~cm}$ and $52.76 \pm 1.13 \mathrm{~cm}$, respectively in Mehraban sheep (Karimi et $a l$.$) .$

The mean facial length, facial width and facial index were $11.53 \pm 0.08 \mathrm{~cm}, 9.30 \pm 0.015 \mathrm{~cm}$ and $80.67 \pm 0.44 \mathrm{~cm}$, respectively; whereas the facial index was $85.44 \pm 1.89 \mathrm{~cm}$ in Mehraban sheep (Karimi et al.) and $138.48 \pm 0.57 \mathrm{~cm}$ in Kagani goat (Sarma). The skull base length was $18.31 \pm 0.02$ $\mathrm{cm}$ in blackbuck measured from the ventral surface of the skull. 
The orbits (Fig. 3) were complete, oval and placed rostro-laterally formed by the frontal, lacrimal and zygomatic bones; the highest contribution in the formation of the bony orbit was by the frontals followed by the zygomatic and the lacrimal, which was similar to the findings in Kagani goat (Sharma); whereas the orbits were elliptical ovoid and orbital margin were incomplete in tiger (Taluja et al., 2000). The orbital rim was almost circular in shape in blackbuck which was similar to the findings in horse (Getty); whereas in the orbital rim was elliptical in Mehraban sheep (Karimi et al.).

Various orbital parameters showed bilateral variation among the orbits of both the sides. The orbital length and height $(4.22 \pm 0.009 \mathrm{~cm}$ and $3.86 \pm 0.005 \mathrm{~cm}$, respectively) was more in left than right orbit $(4.04 \pm 0.007 \mathrm{~cm}$ and $3.81 \pm 0.004$ $\mathrm{cm}$, respectively), which was disagreement with the finding of Sarma where orbital length was more in left orbit, while the right orbit showed more orbital height. Similarly, orbital depth and circumference were recorded more in the right orbit (4.66 \pm 0.004 and $13.49 \pm 0.009 \mathrm{~cm}$, respectively) than the left one ( $4.61 \pm 0.003$ and $13.09 \pm 0.01 \mathrm{~cm}$, respectively) in blackbuck.

The average maximum height, length and depth of the orbit were $3.83 \pm 0.02 \mathrm{~cm}, 4.13 \pm 0.02 \mathrm{~cm}$ and $4.61 \pm 0.008$ $\mathrm{cm}$, respectively. The orbital area, circumference and the orbital index were $12.46 \pm 0.10,13.29 \pm 0.06$ and $107.33 \pm 0.41$ $\mathrm{cm}$, respectively; whereas the orbital index was 155 in tiger (Taluja et al.). While according to Karimi et al. in Mehraban sheep, the orbital length, width and the orbital index were $3.64 \pm 0.05,5.11 \pm 0.13$ and $21.46 \pm 0.68 \mathrm{~cm}$, respectively. The orbital capacity was $26.25 \pm 0.50 \mathrm{~cm} 3$ in blackbuck.

The cranial cavity was an ovoid cavity being elongated posteriorly, situated on the dorsal aspect of the nasal sinus. The capacity of cranial cavity was $107.83 \pm 0.86$ cm3 in blackbuck, while it was $130.86 \pm 11.55 \mathrm{~cm} 3$ in Mehraban sheep (Karimi et al.) and $113 \pm 0.84 \mathrm{~cm} 3$ in Kagani goat (Sarma).

The foramen magnum (foramen occipital magnum) was large and roughly oval in shape similar to observations of Raghavan in ox and Kumawat et al. in chital but disagreement with Getty in horse where foramen magnum was almost circular opening. The height, width, circumference and area of the foramen magnum in blackbuck were $1.74 \pm 0.008 \mathrm{~cm}, 2.03 \pm 0.006 \mathrm{~cm}, 8.22 \pm 0.01 \mathrm{~cm}$ and $0.88 \pm 0.006 \mathrm{~cm}^{2}$, respectively; while according to Sarma, height, width, circumference and area of the foramen magnum was $3.08 \pm 0.35 \mathrm{~cm}, 3.12 \pm 0.36 \mathrm{~cm}, 12.30 \pm 0.28 \mathrm{~cm}$ and $2.53 \pm 0.58 \mathrm{~cm}^{2}$, respectively. Yahaya et al. (2013) noted a mean foramen magnum height and width of $4.04 \pm 0.15$ and $3.70 \pm 0.16 \mathrm{~cm}$, and $3.65 \pm 0.27$ and $3.45 \pm 0.21 \mathrm{~cm}$ in males and females of one humped camel. The foramen index was 98.71 in the present study, which was $109.30 \pm 4.44$ and $107.37 \pm 6.33$ (more than 100) in males and females of one humped camel.

The distance from the facial tuberosity to the infraorbital canal and from the latter to the root of the alveolar tooth directly ventral to it, were $2.37 \pm 0.006 \mathrm{~cm}$ and $0.72 \pm 0.01 \mathrm{~cm}$, respectively in blackbuck; while in West African Dwarfs goats were 1.6-1.8 cm and 1.3-1.6 cm (Olopade \& Onwuka, 2005); in Gwembe Valley dwarf goat were $2.06 \pm 0.14 \mathrm{~cm}$ and $1.13 \pm 0.11 \mathrm{~cm}$ (Kataba et al., 2014); in Iranian native cattle were $2.8 \mathrm{~cm}$ and $2.5 \mathrm{~cm}$ Monfared (2013). Uddin et al. (2009) also reported same measurements for Black Bengal goat were $1.85 \pm 0.14 \mathrm{~cm}$ and $1.75 \pm 0.19$ $\mathrm{cm}$. The maximum length and width of the premaxilla was $7.23 \pm 0.007 \mathrm{~cm}$ and $1.00 \pm 0.001 \mathrm{~cm}$, respectively. The maximum length and width of palatine bone was $6.04 \pm 0.046$ $\mathrm{cm}$ and $3.23 \pm 0.022 \mathrm{~cm}$, respectively. The average maximum length and width of nasal bone was $5.69 \pm 0.01 \mathrm{~cm}$ and $1.29 \pm 0.01 \mathrm{~cm}$, respectively; whereas length and width of nasal bone were $6.50 \pm 0.11 \mathrm{~cm}$ and $3.20 \pm 0.57 \mathrm{~cm}$, respectively in Kagani goat (Sarma).

The distance between the lateral end of the alveolus of the third incisor tooth to the mental foramen was $2.45 \pm 0.008$; which was an important landmark for achieving the location of the mental nerve for the regional nerve block in blackbuck while it was $1.6 \pm 0.22 \mathrm{~cm}$ and $2.0 \pm 0.30 \mathrm{~cm}$ in West African Dwarf goat and Red Sokoto (Maradi) goat of Nigeria, respectively (Olopade \& Onwuka, 2005, 2007).

The length and height of the mandible was $16.53 \pm 0.128 \mathrm{~cm}$ and $10.69 \pm 0.024 \mathrm{~cm}$ respectively in blackbuck which was higher than the value obtained for West African Dwarfs goats of Nigeria as $12.00 \pm 1.89 \mathrm{~cm}$ and $6.90 \pm 1.09 \mathrm{~cm}$, respectively (Olopade \& Onwuka, 2005); whereas the length and height of the mandibles were 27.40 $\mathrm{cm}$ and $15.88 \mathrm{~cm}$, respectively in Iranian native cattle (Monfared). Kataba et al. had observed the length and height of mandible as $11.24 \pm 0.52 \mathrm{~cm}$ and $6.64 \pm 0.44 \mathrm{~cm}$ respectively, in Gwembe Valley dwarf goat.

\section{ACKNOWLEDGEMENTS}

The authors are grateful to the Ministry of Environment of Forests (MoEF), New Delhi and Jodhpur Zoo for providing facilities and support for carrying out research on bones of blackbuck. Funding was provided by the Department of Science and Technology, New Delhi, India as Ph.D. grant (DST-INSPIRE Fellowship) to first author. 
CHOUDHARY, O.P. \& SINGH, I. Estudios morfométricos en el cráneo del antílope indio (Antelope cervicapra). Int. J. Morphol., 33(3):868-876, 2015.

RESUMEN: La apariencia fenotípica de la cabeza de especies animales depende principalmente de la forma del cráneo. Los estudios morfométricos del cráneo muestran que la variabilidad en la forma y proporciones de los huesos está influenciada por factores genéticos y ambientales. El presente estudio se llevó a cabo por primera vez en las características morfométricas en el cráneo del antílope indio. En este estudio se efectuaron mediciones craneométricas en 48 partes de los cráneos de antílope indio. Todas las características investigadas se expresaron como Media \pm EE. Las mediciones craneométricas e índices cefálicos fueron comparados con los rumiantes. Se encontró que las longitudes medias de los cráneos eran de 20,68 $\pm 0,02 \mathrm{~cm}$, con el ancho y el índice cefálico de $9,54 \pm 0,03 \mathrm{~cm}$ y $46,12 \pm 0,12 \mathrm{~cm}$, respectivamente. La longitud del cráneo, ancho y alto en antílope indio eran $10,40 \pm 0,02 \mathrm{~cm}, 6,13 \pm 0,02$

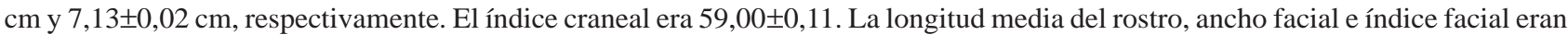
$11,53 \pm 0,08 \mathrm{~cm}, 9,30 \pm 0,01 \mathrm{~cm}$ y $80,67 \pm 0,44 \mathrm{~cm}$, respectivamente. El peso medio del cráneo con la mandíbula en el antílope indio fue de $182,37 \pm 0,54$.

PALABRAS CLAVE: Antílope indio; Cráneo; Morfométrico; Índice cefálico; Índice craneal.

\section{REFERENCES}

Bruenner, H.; Lugon-Moulin, N.; Balloux, F.; Fumagalli, L. \& Hausser, J. A taxonomical re-evaluation of the Valais chromosome race of the common shrew Sorex araneus (Insectivora: Soricidae). Acta Theriol., 47(3):245-75, 2002.

Evans, K. E. \& McGreevy, P. D. Conformation of the equine skull: a morphometric study. Anat. Histol. Embryol., 35(4):221-7, 2006.

Getty, R. Sisson and Grossman's The Anatomy of the Domestic Animals. Vol. I, 5th ed. Philadelphia, W.B. Saunders Co., 1975.

Joshi, H. Gross anatomical studies of the skull of Indian tiger (Panthera tigris). Thesis M.V.Sc. Bikaner, Rajasthan Agricultural University, 2004.

Karimi, I.; Onar, V.; Pazvant, G.; Hadipour, M. \& Mazaheri, Y. The cranial morphometric and morphologic characteristics of Mehraban sheep in Western Iran. Glob. Vet., 6(2):111-7, 2011.

Kataba, A.; Mwaanga, E. S.; Simukoko, H. \& Parés, C. P. M. Clinical anatomy of the head region of Gwembe Valley dwarf goat in Zambia. Int. J. Vet. Sci., 3(3):142-6, 2014.

Kumawat, R.; Joshi, S.; Mathur, R. \& Choudhary, O. P. Gross Anatomical Studies on the Cranial Bones of Skull in Chital (Axis axis). Indian J. Vet. Anat., 26(1):54-5, 2014.

Künzel, W.; Breit, S. \& Oppel, M. Morphometric investigations of breed-specific features in feline skulls and considerations on their functional implications. Anat. Histol. Embryol., 32(4):218-23, 2014.

McGreevy, P.; Grassi, T. D. \& Harman, A. M. A strong correlation exists between the distribution of retinal ganglion cells and nose length in the dog. Brain Behav. Evol., 63(1):13-22, 2004.

Miller, M. E.; Christensen, G. C. \& Evans, H. E. Anatomy of the Dog. Philadelphia, W. B. Saunder's Company, 1964.
Monfared, A. L. Gross Anatomical measurements of the head region of the iranian native cattle (Bos taurus) and their clinical value for regional anesthesia. Glob. Vet., 10(2):219-22, 2013.

Olopade, J. O. \& Onwuka, S. K. Osteometric studies of the skull of red Sokoto (Maradi) goats (Capra hircus): Implications for regional anaesthesia of the head. Int. J. Morphol., 25(2):407-10, 2007.

Olopade, J. O. \& Onwuka, S. K. Some aspects of the clinical anatomy of the mandibular and maxillofacial regions of the west african dwarf goat in Nigeria. Int. J. Morphol., 23(1):33-6, 2005.

Olopade, J. O. \& Onwuka, S. K. A review of the craniofacial and neurometric anatomy of the goat. Trop. Vet., 27(4):1-19, $2009 \mathrm{~b}$.

Olopade, J. O. \& Onwuka, S. K. Morphometric analysis of the skull of the Sahel goat breed: basic and clinical anatomy. Ital. J. Anat. Embryol., 114(4):167-78, 2009a.

Olopade, J. O. \& Onwuka, S. K. Morphometric studies of the craniofacial region of the West African Dwarf Goat in Nigeria. Int. J. Morphol., 22(2):145-8, 2004.

Onar, V. \& Günes, H. On the variability of skull shape in German shepherd (Alsatian) puppies. Anat. Rec. A Discov. Mol. Cell. Evol. Biol., 272(1):460-6, 2003.

Parés, I.; Casanova, P. M.; Kamal, S. \& Jordana, J. On biometrical aspects of the cephalic anatomy of Xisqueta Sheep (Catalunya; Spain). Int. J. Morphol., 28(2):347-351, 2010.

Raghavan, D. Anatomy of the ox; with comparative notes on the horse, dog and fowl. New Delhi, Indian Council of Agricultural Research, 1964.

Rogers, T. L. Determining the sex of human remains through cranial morphology. J. Forensic. Sci., 50(3):493-500, 2005. 
Sarma, K. Morphological and craniometrical studies on the skull of Kagani goat (Capra hircus) of Jammu region. Int. J. Morphol., 24(3):449-55, 2006.

Singh, P. Gross anatomical studies on the skull of camel (Camelus dromedarius). Thesis M.V.Sc. Hisar, Haryana Agriculture University, 1984.

Sisson, S. Ruminant Osteology. In: Sisson, S.; Grossman, J. D. \& Getty, R. (Eds.). Sisson and Grossman's The Anatomy of the Domestic Animals, Getty R. 5th ed. Philadelphia, W. B. Sounder's Co., 1964.

Snedecor, G. W. \& Cochran, W. G. Statistical Methods. 8th ed. Ames, Iowa State University Press, 1994.

Taluja, J. S.; Malik, M. R. \& Parmar, M. L. Orbitometry of tiger. In: Proceedings of XV convention of Indian Association of veterinary Anatomists and National Symposium. Dec. 23-25, 2000. Madras Veterinary College, Chennai, India.

Uddin, M. M.; Ahmed, S. S. U.; Islam, K. N. \& Islam, M. M. Clinical anatomy of the head region of the Black Bengal goat in Bangladesh. Int. J. Morphol., 27(4):1269-73, 2009.

Yahaya, A.; Olopade, J. O. \& Kwari H. D. Morphological analysis and osteometry of the foramen magnum of the one-humped camel (Camelus dromedarius). Anat. Histol. Embryol., 42(2):155-9, 2013.

Zhu, L.; Shi, X.; Wang, J. \& Chen, J. G. A morphometric study on the skull of donkey (Equus asinus). Int. J. Morphol., 32(4):1306-10, 2014.
Correspondence to:

Dr. Ishwer Singh

Professor and Head

Department of Veterinary Anatomy

College of Veterinary and Animal Science

G.B. Pant University of Agriculture and Technology

Pantnagar-263 145

INDIA

Email: Singh_iswar@yahoo.co.in
dr.om.choudhary@gmail.com

Received: 13-02-2015

Accepted: 20-05-2015 